\title{
Students' Perceptions on DeFleur Communication Model in Sprechfertigkeit Teaching for High School Students
}

\author{
Syukur Saud, Wahyu Kurniati Asri, Burhanuddin \\ Universitas Negeri Makassar \\ syukursaud@gmail.com
}

\begin{abstract}
German is one of the most difficult foreign languages taught in Indonesian high schools. Teaching German effectively can be determined by the way teachers communicate with students. This research aims to explore the students' perceptions on the application of Defleur communication model in teaching Sprechfertigkeit in high schools. This quantitative study employed 4 schools through representative samplings with total of 100 students. The results of the study indicated that two major elements of DeFleur communication model which were credibility and attractiveness influenced the teaching Sprechfertigkeit in high schools. This research is significant for the improvement of German teaching program in other high schools both nationally and internationally.
\end{abstract}

Keywords: Defleur model of Communication, German, Sprechfertigkeit Teaching

\section{INTRODUCTION}

German language as one of the foreign languages can be considered as one of the most complicated subjects in schools. To master German, learners need string motivation and perseverance. In addition, the way teachers communicate their teaching materials in systematic, well-planned, and contextual manners will lead the German language learners to master the basic skills of a language, such as listening, speaking, reading, and writing.

In teaching German language in high schools, students are taught the materials with the emphasis on the mastery of language skills and cultural knowledge. Based on the high school curriculum, students are obliged to master five basic competencies, namely Schreibfertigkeit, Leseverstehen, Hörverstehen, Sprechfertigkeit, and Strukturen und Wortschatz as the complement. The competencies must be mastered well and correctly by all students. In the classroom learning, the competences are implemented gradually from class X to class XII (Ministry of Education and Culture, 2013).

From competencies mentioned above, speaking skill determines the language learners to succeed or fail in learning the language. In addition, speaking skill is one of the main objectives to be achieved by foreign language learners. They certainly will endure failure when they are not able to master the particular competency (Mulyasa, 2007). Although there are stages in the mastery of speaking in German, the ability to express orally has become the evidence of the process of learning a foreign language. Thus the interaction with native speakers can help foreign language learners to master speaking skills.

In many schools, German becomes one of the selected foreign language subjects in Science Program (IPA), Social Studies (IPS) and Language Programs from grade $\mathrm{X}$ to XII. The evidence of mastery in speaking German, for example in Maros Regency, is that senior high school students have low ability to speak German well. It is proved by the average of national exam result of Language Program of 5.25 and in Science Program and Social Studies of 5.10 (Maros Department of Education, 2011).

Similarly, based on the results of preliminary observation at senior high schools in South Sulawesi, many students find it difficult to speak, express their taught and feeling using German. In addition, only very few students who learn German can speak the language fluently. Therefore, the mastery of German particularly speaking skill is very low and the students' competencies are weak too.

In response to this phenomenon, one of the ways to improve the students' language skills, especially speaking skill is that the use of DeFleur communication model that can help learners to learn, organize, systematize and enhance students' learning passion. This paper accounts the importance of implementing DeFleur communication model in teaching Sprechfertigkeit to the students of XII class at senior high schools.

\section{LITERATURE REVIEW}

\section{Concept of Communication}

Arifin (1984, p. 14) argued that "communication [in German] is a joint effort with other people, or to build togetherness with others to form relation". Cangara (2000, p.19) added that communication is "a transaction, symbolic process that requires people to organize their environment by building up the relationship among humans, through the exchange of information to strengthen the attitudes and behavior of other people and try to change attitudes and behavior". Based on some opinions above, it can be concluded that communication is an activity that generally involves two people or more in the communicative activity as the medium for conveying, receiving message and providing language symbols to receiver in order to form the same perceptions. 
Instructional Communication in Teaching and Learning Process

Instructional communication in teaching and learning process has some functions. Mulyana (2007) explained that communication functions were related to content and relationships. Content function involves the information exchange that we need to complete the task, and relationship function involves the information exchange about our relationship with others. If it is viewed from the perspective of teaching and learning process, communication can be described as the process of conveying ideas, messages, meanings and concepts deliberately, and it is planned to be allocated to the communicants (students) (DeVito, 1997). In this case, the messages delivered to the communicants (students) by the teachers is the form of their responsibilities professionally in order to build students' positive personality and optimal learning results.

Saud (2011) added that a teacher as a communicator must have the ability to communicate the learning materials with appropriate methods, so that the students as the communicant are encouraged to learn a foreign language (German) and try to improve their knowledge and behavior holistically. In addition, Sudjana (2003) argued that a teacher has to be aware of four important issues in the teachinglearning process, namely the objective of teaching process, the teaching materials, methods, and learning tools. Those components are not independent, but are interrelated and mutually influencing among others. Schematically, the four components can be shown in the picture below:

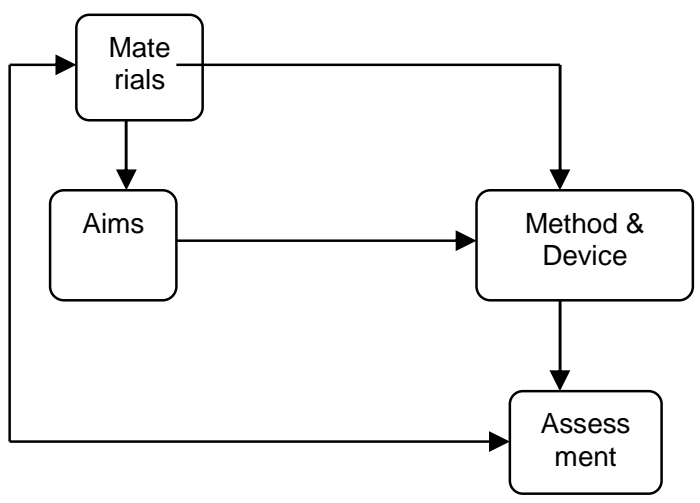

Figure 1. Teaching Components Interaction Source : Sudjana (2003, p. 30)

Thus, it can be interpreted that instructional communication deals with teacher's step as the communicator in teaching and learning process to provide information and knowledge to the students particularly in teaching German. The teaching of German language should be based on learning objectives, preparation of teaching materials, appropriate approaches, methods and appropriate teaching media in the teaching-learning process in order to obtain maximum learning outcomes.
The Function of Communication

According to Cangara (2000, p. 61), there are several functions of communication: a) Information, data collection, storage, processing, dissemination of news, data, images, facts, messages, opinions and comments needed to be understood and act clearly toward environmental conditions and others in order to produce the right decision; b) Socialization, providing a source of knowledge that allows people to be and act as an effective member of society so that he/she is aware of social function and can be active in the society; c) Motivation, explaining the purpose of each community with short term and long term, encouraging people to determine choice and desire, encouraging activities of individuals and groups based on common goals to be pursued; d) The debates and discussions, providing and exchanging necessary facts to allow the approval or to accomplish the differences of opinion on public issues, providing relevant and necessary evidence for the public interest so that the people involved with issues of mutual concern; e) Education, the transfer of knowledge can encourage intellectual development, the building of character, and the formation the necessary skills and proficiency in all areas of life; f) Promoting life, disseminating the results of culture and art with the intention of preserving the legacy of the past, developing culture by opening horizon, as well as building imagination and encouraging creativity and the need of aesthetic; g) Entertainment, dissemination of signals, symbols, sounds, and images of drama, dance, art, literature, music, sports, hobbies of groups and individuals; and h) Integration, providing for nation, groups, and individuals in terms of having chance to obtain the needed messages so that they can know and understand among others as well as respecting conditions of the views and wishes of others.

\section{Learning Model Based DeFleur Communication}

Model is "a systematic representation and abstract which describes the particular potentials relating to various aspects of a process" (Cangara, 2000, p. 39). The learning model is a learning plan that will serve as a guide in the implementation of teaching and learning process in the classroom or tutorial learning and to determine the learning devices, including books, movies, computers, curriculum, and others. Each learning model directs educators in designing learning to help students as much as possible in achieving the learning outcome. 


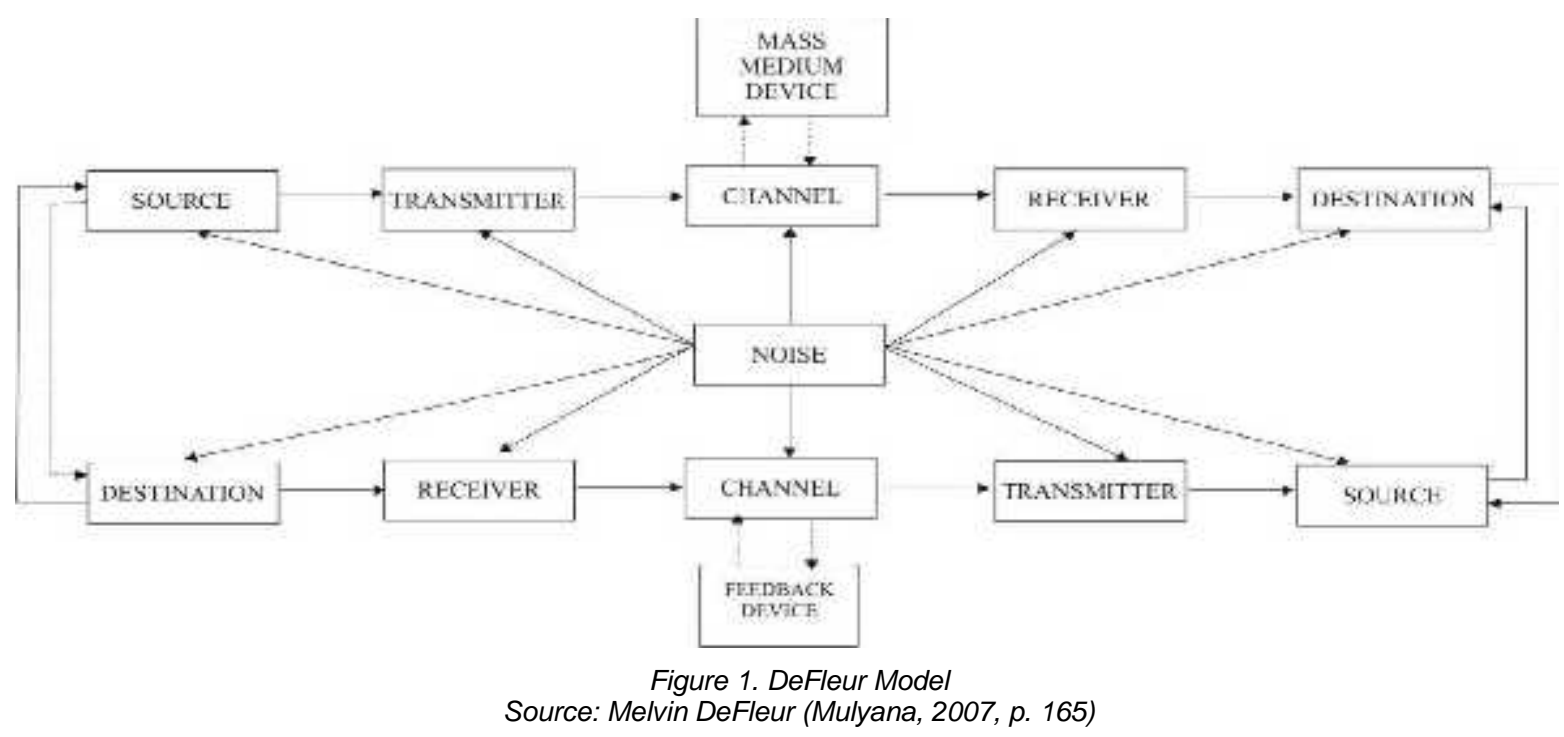

For the purpose of this study, communication by Melvin L. Defleur's model (Mulyana, 2007) is used. As acknowledged by DeFleur, his model is the extension of the models proposed by other experts, especially Shannon and Weaver, by incorporating the mass media and feedback devices. He described the source (source, transmitter, channel, receiver, and destination in the process of mass communication). Transmitter and receiver in the DeFleur model are like transmitter and receiver of Shannon and Weaver's model, which is parallel with the encoder and decoder of the Schramm's model. Source and transmitter are two phases or two different functions carried out by someone.

When someone speaks, he/she chooses symbols to express denotative and connotative meaning (formulating meaning in to message) and then say it verbally or write these symbols that turn into events that can be heard or seen to percept as a stimulus by audience. The functions of receiver in DeFleur's model are to accept information and encode-change physical information event into messages (significant symbol system). In ordinary conversation, this receiver refers to the human hearing apparatus, which receives air vibrations and converts them into nerve impulse, so the verbal symbols can be known. DeFleur's communication model can be seen in Figure 1 below

All of the processes of communication originate from the sources which is the sender of information. For teaching purposes, the source can consist of one person or groups, such as teaching staff (lecturers, teachers) parties, organization or institution.

Speaking skill

Ministry of Education and Culture (2013, p. 147) provided a definition of skills as "the ability to complete the task". Skills are the strengths possessed by someone in a particular field obtained through learning and good training process. In terms of linguistic definition, it is related to one's ability to put on language in writing, reading, listening or speaking. Based on some opinions above, it can be stated that skill is someone's expertise in a particular field in completing tasks obtained through learning and practice with concentration, high consistency and cognitively tangible, affective and psychomotor.

Tarigan (2008) states that speaking is a tool to communicate the ideas prepared and developed according to the needs of the listeners. According to Trianto (2010, pp. 3946), the basic concept of speaking as a means of communication covering nine items, namely: (a) speaking and listening are two reciprocal activities; (b) speaking is an individual process of communicating; (c) speaking is creative expression; (d) speaking is a behavior; (e) speaking is a learned behavior; (f) speaking is stimulated by the experience; (g) speaking is a tool to expand the horizons; (h) the ability of linguistics and the environment. Based on this, it is concluded that speaking skill is expertise belongs to someone in conveying the message/intention of the speaker to the receiver which can be gained through learning and practice.

\section{METHOD}

The design of this study was a quantitative research. The participants of this study were 100 students from 4 schools taken through representative sampling. The four schools were (1) SMA Negeri 16 (SMA 16) Makassar representing central part of South Sulawesi; (2) SMA Negeri 1 Maiwa (SMAN 1 Maiwa), Enrekang representing north part of South sulawesi; (3) SMA Negeri 1 Takalar (SMAN 1 Takallar), representing south part of South Sulawesi; and 4) SMA Negeri 10 (SMAN 10) Simbang Maros representing eastern part of South Sulawesi.

To explore the implementation of DeFleur communication model in teaching Sprechfertigkeit, the researchers used was Likert scale questionnaires (appendix 1). The questionnaires were sent to students in the four schools. 25 students from each school filled the questionnaires, with the total 100 students. The data analysis of Likert scale was analyzed and tabulated through Ms Excel. 


\section{RESULTS AND DISCUSSION}

The result of the research can be categorized into two major themes:
a. Credibility: skill and trust
b. Attractiveness: similarity and closeness

\section{Credibility}

Credibility is one of the important communication models to determine the success of messages or learning materials delivered and the assessment depends on the communicants' perception or students to the communicator or teacher (Bolton, 1995). Teachers who have high credibility always pay attention to the delivery of materials and adjustment to the students' nature and position both by the level and by grade levels. If teachers can communicate effectively, the messages or learning materials presented would lead to changes in students' positive attitudes and behaviors. The most important credibility components are skill and trust, which is described next.

\section{Skill}

Skill is the assessment on capabilities, smartness, and experience of a teacher as a communicator (Tarigan, 2008). The skill level of a teacher as a communicator in teaching Sprechfertikeit was obtained through four questions in Likert scale. This skill item outlines to what extent the teacher's mastery level in terms of materials and approaches in teaching Sprechfetigkeit at senior high school, Figure 2 below.

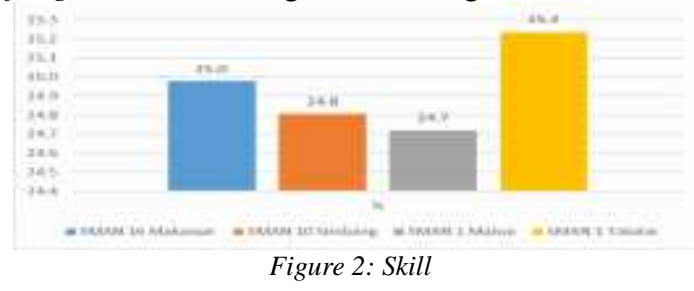

As can be seen from the Figure 2, it is noted that levels of teachers' skill in teaching the German language in particular Sprechfertigkeit are not significantly different, except for SMAN 1 Takalar. It has the highest score of 293 (25.2\%) from four schools. SMAN 16 Makassar achieves score of 290 (25\%), while SMAN 10 Simbang Maros achieves score of 288 $(24.8 \%)$ and SMAN 1 Maiwa has the lowest score of 287 $(24.9 \%)$.

Based on the calculation of the results, it can be stated that the communication skills of teachers were very good particularly teachers in SMAN 1 Takalar. They were very good in teaching Sprechfertigkeit because they mastered the subject well. In comparison to SMAN 1 Maiwa that teachers' skills in teaching speaking are still low.

In general, students wish their teachers to master the materials taught, including the mastery all forms of Sprechfertigkeit components. These can be reflected teacher's ability to answer any questions raised students. In addition, students expect their teachers constantly motivate students to learn the German language, especially Sprechfertigkeit skill.

\section{Trust}

The trust on teacher as communicator reflects that messages delivered to students as communicants are considered correct and in accordance with empirical reality. The data of the students trust level in teaching Sprechfertigkeit described in 2 items covering openness to accept criticism and suggestions as well as to be brave in admitting mistakes teacher as a communicator in conveying the message (learning material) to students (communicant). The trust items are in Figure 3:

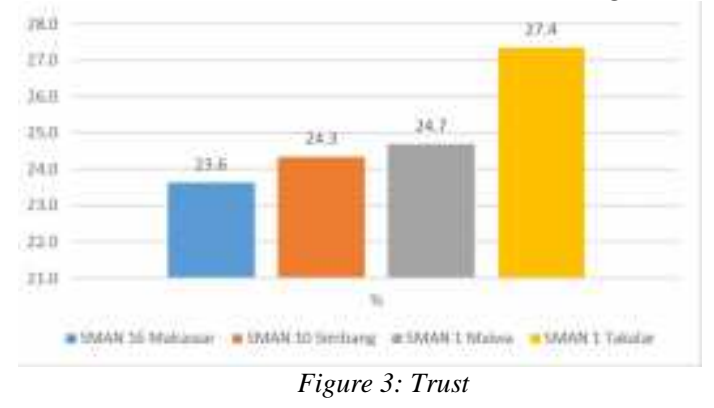

Based on data analysis, it can be noted the level trust of the teachers in teaching the German language in particular Sprechfertigkeit quite varied. SMAN 1 Takalar has the highest score of 154 (27.6\%) from four schools. SMAN 10 Simbang Maros achieved score of 137 (24.3\%), SMAN 1 Maiwa achieved score of 139 (24.7\%), and SMAN 16 Makassar was the lowest score of $133(23.6 \%)$.

In trust indicator, it was obtained the information that the respondents expected their German language teachers to be more open to criticism and suggestions from the students. They also wanted the teachers not to be angry and but be brave to admit the mistakes that might occur during the teaching process. Furthermore, the respondents did not want if their teachers did not provide the opportunity for students to ask questions, they were expected to give assistance in completing and solving problems if the students had difficulties. The respondents did not want the teachers to discriminate very good and poor students, and also discriminate in giving scores. The result analysis of trust indicator that should be owned by German language teachers gives an indication of the overwhelming expectations and wishes of the students in fulfilling the communication elements in the learning process of German language.

\section{Attractiveness}

Physical appearance is the teachers' physical outlook. Teacher has the ability to change attitudes through the physical mechanism, for example, be liked or be admired that allows students to receive and feel comfortable in the teaching and learning process. Besides, appeal is due to the similarity factor between teachers and students, allowing them to listen to materials communicated and explained by the teacher. Similarity, familiarity, and physical appeal are related with appeal. The assessment of the teachers' appearance as communicators in detail can be described as follows: 


\section{Similarity}

In this case, the learning materials should have a special similarity in accordance with the students' needs, the similarity in experience about the message, and the role of message in meeting the needs of the recipient. Teachers and students are expected to have the same perception that the Sprechfertigkeit learning process was going well so that all of the objectives in teaching German language in particular Sprechfertigkeit could be achieved as the target. The data of the students' similarity rate in Sprechfertigkeit were obtained in 5 items included a sense of need, pleasure, mastered German language, got high scores, and can be a German language teacher. The fifth items can be described in detail as follows:

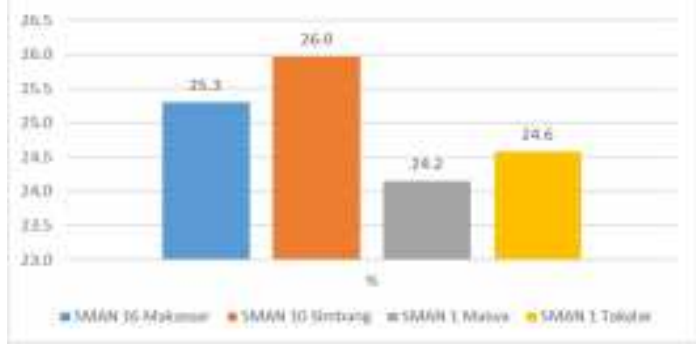

Figure 4: Similarity

It can be argued that similarity aspects in teaching German language in particular Sprechfertigkeit are different (Figure 4). SMAN 10 Simbang Maros has the highest score of 428 (26\%) of the four schools. SMAN 16 Makassar achieved a score of 417 (25.3\%), while SMAN 1 Takalar obtained score of 405 $(24.6 \%)$ while SMAN 1 Maiwa has the lowest score of 1398 $(24.2 \%)$.

Concerning the similarity in German language learning process, the respondents argued that the German language was an important lesson that must be mastered. They also expected that the German language is one of the favorite areas of study. In addition, the analysis of the indicators is that students among four schools had the same perceptions, in which German language learning process was going well in schools. Therefore, the objectives in teaching German language in particular Sprechfertigkeit can be achieved according to the target.

\section{Closeness}

The more the teachers establish good relationships with students in the context of learning, the more they can learn on their students, and vice versa. So with such closeness, a teacher can easily find for a solution in order to foster motivation and comfort for students to learn the German language, especially Sprechfertigkeit. There are four items in a Likert scale that describes the functions of closeness in teaching the German language, especially Sprechfertigkeit including the smartness of teachers, persistence, guidance and motivation, and being able to accept criticism, in Figure 5:

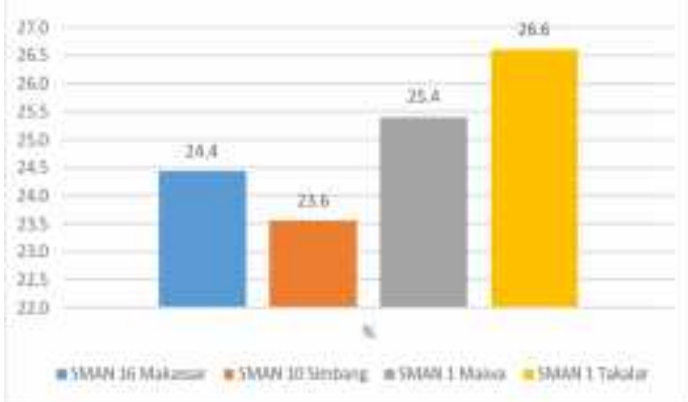

Figure 5: Closeness

Figure 5 indicated that these closeness aspects in teaching German language in particular Sprechfertigkeit are quite varied. SMAN 1 Takalar has the highest score of 331 (26.6\%) of the four schools. SMAN 16 Makassar achieved a score of $304(24.4 \%)$, while SMAN 1 Maiwa obtained score of 316 (25.4\%) while SMAN 10 Simbang Maros has the lowest score of $293(23.6 \%)$

Regarding the closeness indicators, teachers and students require good communication. They try to build a closeness atmosphere through communication. In addition, the students expected that the spirit of learning is encouraged because their German language teachers always encourage their motivation to learn (Saud, 2013).

Based on the analysis results about of the communicators' characteristics (concerning credibility/trust and attractiveness category), it can be concluded that in the German learning process in particular in teaching Sprechfertigkeit, the students expected good communications. It can be seen from the respondents' desire in providing answers or choices to any points in statements or questions in the research instrument in the form of Likert scale. In addition, the teachers have already implemented or applied the DeFleur communication elements (Mulyana, 2004) in the learning process. The implication is that some elements of DeFleur model need to be further explored and investigated.

\section{CONCLUSION}

The communication elements offered by DeFleur model which were credibility and attractiveness can influence the delivery of Sprechfertigkeit in high schools. In addition, teachers who have credibility tend to be able to teach confidently and communicatively. It is clearly indicated that DeFleur model offered the way for teachers to successfully deliver teaching message effectively. Based on these findings, the development and the application of DeFleur learning model can be one of the solutions for teachers and students in Sprechfertigkeit learning in the classroom.

\section{REFERENCES}

Arifin, A. (1984). Strategi Komunikasi. Bandung: Armico. Bolton, S. (1995). Probleme der Leistungsmessung, Lernfortschrittstests in der Grundstufe, Munchen: Langenscheidt. 
Cangara, H. (2000). Pengantar Ilmu Komunikasi. Jakarta: PT Raja Grafindo Persada.

DeVito, J. (1997). Komunikasi Antarmanusia. Alih Bahasa. Jakarta: Professional Books.

Maros Department of Education. (2011). Data Ujian Nasional. Maros: Litbang.

Ministry of Education and Culture. (2013). Panduan Pengembangan Bahan Ajar. Jakarta: Depdiknas.

Mulyana, D. (2007). Ilmu Komunikasi: Suatu Pengantar. Bandung: PT. Remaja Rosdakarya.

Mulyana, D. (2004). Komunikasi Efektif: Suatu Pendekatan Lintasbudaya. Bandung: PT. Remaja Rosdakarya

Mulyasa, E. (2007). Standar Kompetensi dan Sertifikasi Guru. Bandung: Remaja Rosdakarya.

Saud, S (2011). Pengembangan Model Komunikasi SMCR Berlo dalam Pengajaran Wortschatz di SMA se Kota Makassar. Makassar: Lembaga Penelitian Universitas Negeri Makassar.

Saud, S (2013). Pengembangan Model Pembelajaran Menulis Bahasa Asing (Jerman) Berbasis Model SMCR Berlo Pada Siswa SMA se-Sulawesi Selatan. Makassar: Lembaga Penelitian Universitas Negeri Makassar.

Sudjana, N. (2003). Dasar-Dasar Proses Belajar Mengajar. Bandung. Sinar Baru.

Tarigan, H.G. (2008). Menulis sebagai Suatu Keterampilan Berbahasa. Bandung: Angkasa.

Trianto. (2010). Mengembangkan Model Pembelajaran Tematik. Jakarta: Prestasi Pustaka Publisher.

\section{Appendix 1: Questionnaire}

\begin{tabular}{cl} 
No. & \multicolumn{1}{c}{ Description } \\
\hline 1 & S love studying the German \\
language subject because the \\
teacher who delivers masters the \\
field.
\end{tabular}

criticism and suggestions from students.

6 The teacher is never angry, but brave to admit the mistake during teaching

7 As a student, I need to learn the German language taught by my teachers because a German language lesson is important to master.

$8 \quad$ I like German language lessons

9 The teachers want their students proficient in field of German language and so do the students.

10 Teacher and I want to obtain high scores.

11 Teacher and I expect that I become a German language teacher in the future

12 Our German language teachers are good at communicating, so teachers and students established closeness

13 Therefore, I am reluctant to German lessons because the teacher is well.

14 My learning motivation is encouraged because my teacher always gives motivation to learn.

15 My German language teacher feels happy if he/she gets criticisms and suggestions from students. 